\title{
TIPE KEPRIBADIAN DAN PERILAKU CARING MAHASISWA SARJANA KEPERAWATAN DI UNIVERSITAS HARAPAN BANGSA
}

\author{
Tri Sumarni ${ }^{1)}$, Arlyana Hikmanti ${ }^{2)}$ \\ ${ }_{1,2}$ Fakultas Kesehatan, Universitas Harapan Bangsa, Banyumas, Indonesia \\ email: trisumarni@uhb.ac.id
}

\begin{abstract}
Abstrak
Perilaku caring merupakan inti dari profesi keperawatan dan dianggap sebagai indikator penting dan dasar bagi pendidikan keperawatan. Sikap dan perilaku individu dipengaruhi oleh ciri kepribadian. Tujuan dari penelitian ini untuk menganalisis hubungan tipe kepribadian dengan perilaku caring mahasiswa keperawatan. Penelitian ini merupakan penelitian deskriptif korelasional dengan pendekatan cross sectional. Sampel penelitian ini adalah mahasiswa program studi sarjana keperawatan sebanyak 250 mahasiswa yang terdiri dari semester 4, 6 dan 8 teknik pengambilan sampel menggunakan total sampling. Instrumen penelitian yang digunakan perilaku caring diadaptasi dari kuesioner Caring Behavior Inventory (CBI) dan kuesioner kepribadian NEO-Five-Factor Inventory oleh McCrae dan Costa. Tipe kepribadian terbanyak yaitu kepribadian conscientiousness (mean 67,89). Perilaku caring responden mayoritas pada kategori baik (88\%). Hubungan tipe kepribadian (big five personality) dengan perilaku caring signifikan pada kepribadian conscientiousness $(r=0,13, p=0,03)$ dan kepribadian agreeableness $(r=0,18, p=0,04)$. Terdapat hubungan antara tipe kepribadian (big five personality) dengan perilaku caring khususnya pada kepribadian conscientiousness dan agreeableness. Proses pembelajaran yang dapat membentuk karakter dan perilaku caring di instansi pendidikan perlu ditingkatkan lagi. Dosen dapat membantu mahasiswa untuk memahami kepribadian masing-masing melalui proses belajar mengajar.
\end{abstract}

Kata kunci: tipe kepribadian, perilaku caring, mahasiswa keperawatan

\begin{abstract}
Caring behavior is at the core of the nursing profession and is considered as an important and basic indicator of nursing education. Individual attitudes and behavior are influenced by personality traits. The purpose of this study was to analyze the relationship between personality types and caring behavior of nursing students. This research is a descriptive correlational study with a cross sectional approach. The sample of this study was 250 undergraduate nursing students of the fourth, sixth and eighth semesters. The sampling technique used total sampling. The research instrument used caring behavior was adapted from the Caring Behavior Inventory (CBI) questionnaire and the NEO-Five-Factor Inventory personality questionnaire by McCrae and Costa. The most personality type is conscientiousness personality (mean 67.89). The majority of respondents caring behavior is in good category (88\%). The relationship of personality type (big five personality) with caring behavior was significant on conscientiousness personality $(r=0.13, p=0.03)$ and agreeableness personality $(r=0.18, p=0.04)$. There is a relationship between personality type (big five personality) and caring behavior, especially conscientiousness and agreeableness personalities. The learning process that can shape the character and behavior of caring in educational institutions needs to be further improved. Lecturers can help students to understand each other's personalities through teaching and learning process.
\end{abstract}

Keywords : personality type, caring behavior, nursing students

\section{PENDAhULUAN}

Caring dipandang sebagai esensi dan komponen kunci profesi keperawatan (Labrague et al., 2015). Caring juga merupakan salah satu kompetensi yang diharapkan dari mahasiswa keperawatan(Labrague, 2012). Sebagai calon perawat, mahasiswa keperawatan diharapkan memiliki perilaku caring yang tepat (Richardson, Percy, \& Hughes, 2015). Watson (2012) berpendapat bahwa caring merupakan konsep utama dalam pendidikan keperawatan. Tujuan dari kurikulum berbasis caring adalah menyediakan 
keseluruhan konsep tentang caring sehingga dapat menjadi dasar mahasiswa dapat berperilaku caring saat sudah menjadi perawat (Zamanzadeh, et al., 2014).

Perilaku caring pada mahasiswa dalam pendidikan keperawatan sangat penting karena merupakan tempat pertama bagi mahasiswa untuk belajar tentang nilai-nilai dan esensi dari profesi mereka (Begum dan Slavin, 2012). Mahasiswa keperawatan adalah seseorang yang dipersiapkan untuk dijadikan perawat profesional di masa yang akan datang. Pendidikan keperawatan mempunyai pengaruh positif terhadap perilaku caring mahasiswa. Mahasiswa yang belum merasakan caring, akan menjadi keras hati, depresi, merasa down, stres dan cemas yang pada akhirnya akan menghambat pembelajaran serta kemampuan dalam melakukan tindakan keperawatan (Roe, 2009). Mahasiswa keperawatan yang merasakan perasaan caring pada saat pembelajaran, maka mahasiswa tersebut akan belajar bagaimana berperilaku caring.

Perilaku caring perawat terhadap pasien dipengaruhi oleh kepribadian (Barnum (1998) \& Melleis (1997) dalam Agustin, 2002)). Perbedaan kepribadian perawat akan mempengaruhi cara perawat dalam berinteraksi memberikan pelayanan keperawatan. Niven (2002) dalam Nasution \& Ariga(2018), menyatakan bahwa kepribadian merupakan hal penting dalam proses interaksi dalam dunia kesehatan karena kemampuan orang berinteraksi dengan pasien sampai batas tertentu ditentukan oleh kepribadian dan interaksi dengan pasien membutuhkan tingkat empati tertentu serta kemampuan melihat masalah dari sudut pandang pasien.

Gunarsa (2010) juga menyatakan hal yang sama dimana seorang perawat dalam pekerjaannya selalu bertemu dengan beraneka ragam kepribadian orang, yang semuanya mempunyai ciri khas masing-masing. Seorang perawat selain harus mengenal perbedaan pada pasien, teman sejawat, supervisor, instruktor, teman, dan keluarganya, harus juga mengetahui bahwa dirinya sendiri juga memiliki perbedaan dan menyadari bahwa ciri-ciri khas tertentu dapat memudahkan usaha untuk mencapai interaksi positif dengan orang lain. Keberhasilan seorang perawat dalam membina pengaruh dengan orang lain tergantung dari pemahaman tentang sifat dan ciri-ciri kepribadian perawat sendiri. Sikap dan perilaku individu dipengaruhi oleh ciri kepribadian.

Kepribadian juga berpengaruh terhadap kinerja seseorang. Penelitian dari Afidah (2011) tentang hubungan antara tipe kepribadian dengan kinerja perawat di Rumah Sakit PKU Muhammadiyah Surakarta membuktikan hal tersebut. Dalam penelitian ini disimpulkan bahwa terdapat hubungan antara tipe kepribadian dengan kinerja perawat. Perawat yang profesional harus memiliki sikap yang respect, empati, sungguhsungguh, tanggung jawab serta sabar terhadap pasien. Ia juga harus percaya diri dan mandiri. Selaras dengan itu Nursalam et al., 2015) menyatakan salah satu ciri perawat profesional adalah mampu memiliki sikap dan perilaku menolong dengan rasa kemanusiaan terhadap pasien. Sikap, perilaku, empati, merupakan elemen dari kepribadian seseorang (Fusnika, 2014). Oleh karena itu seorang perawat yang profesional seharusnya memiliki kepribadian yang baik. Perilaku profesional dari perawat dalam memberikan asuhan keperawatan harus dikembangkan dan dibina sejak awal proses Pendidikan (Sholichah, 2015).

Berdasarkan hasil penelitian Nursalam et al. (2015), tipe kepribadian mahasiswa keperawatan berhubungan dengan persepsi caring mahasiswa keperawatan. Penelitian Pardede (2020) juga menyatakan tipe kepribadian berhubungan dengan perilaku caring perawat.

Berdasarkan pengamatan peneliti terhadap perilaku caring mahasiswa selama praktik di rumah sakit, mahasiswa kurang mempunyai inisiatif untuk mendekati pasien, mahasiswa juga dinilai kurang memahami teori yang dibutuhkan selama mereka praktik. Mahasiswa hanya menunggu perintah untuk melaksanakan tindakan, terlalu banyak menghabiskan waktu di ruangan dan bukan menghadapi pasien, padahal harapan mereka mahasiswa memiliki semangat dalam menemui pasien serta berusaha mencari tahu bagaimana memberikan asuhan keperawatan dengan baik dan benar melalui perilaku caring kepada pasien. Tujuan penelitian ini adalah menganalisis hubungan tipe kepribadian dengan perilaku caring mahasiswa keperawatan Program Studi Sarjana Keperawatan Fakultas Kesehatan Universitas Harapan Bangsa.

\section{METODE PENELITIAN}

Jenis penelitian ini adalah deskriptif korelasional dengan pendekatan cross sectional. Populasi dalam penelitian ini adalah mahasiswa program studi keperawatan S1 di Universitas Harapan Bangsa sebanyak 250 mahasiswa yang terdiri dari semester 4, 6 dan 8 . Teknik pengambilan sampel dengan menggunakan total sampling. Sampel dalam penelitian ini berjumlah 250 responden. 
Variabel independen dalam penelitian ini adalah tipe kepribadian. Sedangkan variabel dependen dalam penelitian ini adalah perilaku caring mahasiswa. Instrumen yang digunakan dalam penelitian ini adalah kuesioner. Kuesioner kepribadian menggunakan NEO-Five-Factor Inventory oleh McCrae dan Costa, terdiri dari 67 pertanyaan (14 pertanyaan untuk kepribadian neuroticism, 14 pertanyaan untuk kepribadian extraversion, 10 pertanyaan untuk kepribadian openness, 12 pertanyaan untuk kepribadian agreeableness, 17 pertanyaan untuk kepribadian conscientiousness). Kuesioner kepribadian diukur dalam bentuk skala likert dimana enam respon diberikan untuk setiap item yaitu: sangat tidak sesuai (1), tidak sesuai (2), agak tidak sesuai (3), agak sesuai (4), sesuai (5), sangat sesuai (6). Berdasarkan nilai mean dan standar deviasi, masingmasing kepribadian dikelompokkan menjadi tinggi, sedang dan rendah.

Sedangkan untuk perilaku caring menggunakan kuesioner Caring Behavior Inventory (CBI). Kuesioner ini terdiri dari 38 item pertaanyaan dengan lima indikator yaitu rasa hormat kepada yang lain atau respectful deference to the other (10 item), jaminan kepastian manusia atau assurance of human precense (11 item), keterhubungan positif atau positive connectedness (9 item), pengetahuan dan keterampilan professional atau professional knowledge and skill (4 item), dan perhatian pada pengalaman orang lain atau attentiveness to the other's experience (4 item). Kuesioner CBI diukur dalam bentuk skala likert dimana empat respon diberikan untuk setiap item yaitu: tidak pernah (1), jarang (2), sering (3), dan selalu (4).
Pengujian instrumen kuesioner dalam penelitian ini menggunakan uji terpakai atau try out terpakai. Berdasarkan hasil uji validitas kuesioner kepribadiandengan rumus Pearson Product Moment dari 67 item didapatkan $r$ hitung $>r$ tabel $(0,361)$ dengan taraf signifikasi 5\%, semua item pertanyaan dinyatakan valid. Uji reliabilitas dengan menggunakan cronbach alphadari instrumen kepribadian didapatkan nilai cronbach alpha $(0,937)$, sehingga dapat disimpulkan bahwa pertanyaan dinyatakan reliabel/ handal.

Sedangkan untuk hasil uji validitas kuesioner perilaku caring dengan rumus Pearson Product Moment dari 43 item didapatkan 38 item dinyatakan valid $r$ hitung $>r$ tabel $(0,361)$ dan 4 item dikatakan tidak valid.Uji reliabilitas yang dilakukan dengan menggunakan rumus cronbach alphadari instrumen perilaku caring didapatkan nilai cronbach alpha $(0,940)$, sehingga dapat disimpulkan bahwa pertanyaan dinyatakan reliabel/ handal.

Analisis data untuk mengetahui hubungan masing-masing variabel independen dengan variabel dependen yang berbentuk skala ordinal digunakan uji korelasi spearman rank.

\section{HASIL DAN PEMBAHASAN}

Tabel 1. Distribusi Frekuensi Perilaku Caring di Prodi Sarjana Keperawatan Fakultas Kesehatan Universitas Harapan Bangsa Tahun 2020

\begin{tabular}{lcc}
\hline \multicolumn{1}{c}{ Perilaku Caring } & Frekuensi & Persentase \\
\hline Baik & 220 & 88 \\
Cukup & 30 & 12 \\
Kurang & 0 & 0 \\
\hline Total & 250 & 100,0 \\
\hline
\end{tabular}

Tabel 2. Distribusi Frekuensi Tipe Kepribadian Mahasiswa di Prodi Sarjana Keperawatan Fakultas Kesehatan Universitas Harapan Bangsa Tahun 2020

\begin{tabular}{llcc}
\hline \multicolumn{1}{c}{ Tipe Kepribadian } & Kategori & Frekuensi & Persentase \\
\hline Kepribadian Neuroticism & Tinggi & 34 & 13,6 \\
& Sedang & 176 & 70,4 \\
Kepribadian Extraversion & Rendah & 40 & 16 \\
& Tinggi & 40 & 16 \\
& Sedang & 171 & 68,4 \\
Kepribadian Openness & Rendah & 49 & 15,6 \\
& Tinggi & 52 & 20,8 \\
Kepribadian Agreeablenes & Sedang & 146 & 62,4 \\
& Rendah & 42 & 16,8 \\
\multirow{3}{*}{ Kepribadian Conscientiousness } & Tinggi & 53 & 21,2 \\
& Sedang & 159 & 63,6 \\
& Rendah & 38 & 15,2 \\
& Tinggi & 41 & 16,4 \\
& Sedang & 157 & 62,8 \\
& Rendah & 52 & 20,8 \\
\hline
\end{tabular}


Tabel 3. Hubungan Tipe Keprbadian dengan Perilaku Caring Mahasiswa Keperawatan S1 di Fakultas Kesehatan Universitas Harapan Bangsa.

\begin{tabular}{|c|c|c|c|c|c|c|c|c|}
\hline \multirow{3}{*}{ Variabel } & & \multicolumn{4}{|c|}{ Perilaku Caring } & \multirow{3}{*}{$\begin{array}{c}\text { Total F } \\
(\%)\end{array}$} & \multirow{3}{*}{$\begin{array}{c}p \\
\text { value }\end{array}$} & \multirow{3}{*}{$\mathbf{C C}$} \\
\hline & & \multicolumn{2}{|c|}{ Baik } & \multicolumn{2}{|c|}{ Cukup } & & & \\
\hline & & $\mathbf{F}$ & $\%$ & $\mathbf{F}$ & $\%$ & & & \\
\hline \multirow[t]{3}{*}{ Kepribadian Neuroticism } & Tinggi & 28 & 82,4 & 6 & 17,6 & $34(13,6)$ & \multirow{3}{*}{0,21} & \multirow{3}{*}{0,079} \\
\hline & Sedang & 156 & 88,6 & 20 & 11,4 & $176(70,4)$ & & \\
\hline & Rendah & 36 & 90 & 4 & 10 & $40(16)$ & & \\
\hline \multicolumn{2}{|l|}{ Total } & 220 & 88 & 30 & 12 & 250 & & \\
\hline \multirow[t]{3}{*}{ Kepribadian Extraversion } & Tinggi & 37 & 92,5 & 3 & 7,5 & $40(16)$ & \multirow{4}{*}{0,6} & \multirow{4}{*}{0,03} \\
\hline & Sedang & 152 & 88,9 & 19 & 11,1 & $171(68,4)$ & & \\
\hline & Rendah & 31 & 79,5 & 8 & 20,5 & $39(15)$ & & \\
\hline \multicolumn{2}{|l|}{ Total } & 220 & 88 & 30 & 12 & 250 & & \\
\hline \multirow[t]{3}{*}{ Kepribadian Openness } & Tinggi & 48 & 92,3 & 4 & 7,7 & $52(20,8)$ & \multirow{4}{*}{0,37} & \multirow{4}{*}{0,056} \\
\hline & Sedang & 139 & 89,1 & 17 & 10,9 & $156(62,4)$ & & \\
\hline & Rendah & 33 & 78,6 & 9 & 21,4 & $42(16,8)$ & & \\
\hline Total & & 220 & 88 & 30 & 12 & 250 & & \\
\hline \multirow[t]{3}{*}{ Kepribadian Agreeablenes } & Tinggi & 48 & 90,6 & 5 & 9,4 & $53(21,2)$ & \multirow{4}{*}{0,04} & \multirow{4}{*}{0,18} \\
\hline & Sedang & 141 & 88,7 & 18 & 11,3 & $159(63,6)$ & & \\
\hline & Rendah & 31 & 81,6 & 7 & 18,4 & $38(15,2)$ & & \\
\hline Total & & 220 & 88 & 30 & 12 & 250 & & \\
\hline \multirow[t]{3}{*}{ Kepribadian Conscientiousness } & Tinggi & 38 & 92,7 & 3 & 7,3 & $41(16,4)$ & \multirow{4}{*}{0,03} & \multirow{4}{*}{0,13} \\
\hline & Sedang & 139 & 88,5 & 18 & 11,5 & $157(62,8)$ & & \\
\hline & Rendah & 43 & 82,7 & 9 & 17,3 & $52(20,8)$ & & \\
\hline Total & & 220 & 88 & 30 & 12 & 250 & & \\
\hline
\end{tabular}

Tabel 1 menunjukkan bahwa dari 250 responden ada 220 responden $(88 \%)$ menyatakan perilaku caring dalam kategori baik dan 30 responden $(12 \%)$ menyatakan perilaku caring kategori cukup. Berdasarkan hasil analisis kuesioner perilaku caring nilai tertinggi diperoleh pada dimensi pengetahuan dan keterampilan profesional (professional knowledge and skill) yaitu pada pernyataan Saat praktik klinik di rumah sakit, saya menjaga kerahasiaan informasi pasien.

Perilaku caring dalam berbagai kajian merupakan esensi dari keperawatan. Perilaku caring berhubungan dengan struktur karakteristik kepribadian yang sesuai dengan pemberian asuhan keperawatan yang secara signifikan menentukan mahasiswa keperawatan dan perawat sukses dalam lingkungan akademik dan tempat kerja dengan meningkatkan kedekatan/ keintiman, empati dan hubungan (Parvan K, Hosseini F, 2012). Perilaku caring pada mahasiswa dalam pendidikan keperawatan sangat penting karena merupakan tempat pertama bagi mahasiswa untuk belajar tentang nilai-nilai dan esensi dari profesi mereka (Begum \& Slavin, 2012 dalam Sumarni, 2020).

Penelitian ini sejalan dengan penelitian dari Nurhayati (2018), tentang Model Peningkatan Perilaku Caring pada Mahasiswa Jurusan keperawatan Politeknik Kemenkes Pangkal Pinang menunjukan dari 69 responden ada 30 responden $(43,5 \%)$ dinyatakan pada kategori baik. Sementara penelitian yang dilakukan oleh Sulisno \& Ulfa (2015), tentang Interaksi caring mahasiswa keperawatan Tingkat I, II dan III menunjukkan dari 184 responden ada 130 responden $(70,7 \%)$ dinyatakan interaksi caring cukup baik.

Nadelson (2010) dalam Sumarni (2020) menyatakan bahwa perilaku caring mahasiswa keperawatan dipengaruhi oleh umur dan persepsi tentang perilaku caring teman sekelompok. Nursalam et al. (2015) menyatakan bahwa perilaku caring mahasiswa dipengaruhi oleh faktor individu (demografi, pengetahuan, keterampilan), faktor psikologi (kepribadian, kecerdasan emosional, motivasi) dan faktor organisasi (beban kerja/ tugas). Sumarni (2016) juga menyatakan kecerdasan emosional mahasiswa keperawatan berhubungan dengan perilaku caring.

Hasil penelitian (Tabel 3) menunjukkan bahwa kepribadian berhubungan dengan perilaku caring mahasiswa keperawatan. Karakteristik kepribadian yang sesuai dengan pemberian asuhan keperawatan dapat secara signifikan menentukan mahasiswa keperawatan dan perawat sukses dalam lingkungan akademik dan tempat kerja dengan 
meningkatkan kedekatan/ keintiman, empati dan hubungan (Parvan K, Hosseini F, 2012).

Tabel 2 memberikan informasi bahwa nilai mean tertinggi kepribadian mahasiswa keperawatan pada kepribadian conscientiousness dan terendah di kepribadian Neuroticism. Lima faktor kepribadian adalah salah satu hal yang diperlukan berkaitan dengan kinerja seseorang (Eley et al., 2012). Hasil penelitian menunjukkan bahwa kepribadian conscientiousness memiliki mean tertinggi. Tipe kepribadian ini menggambarkan perilaku yang berorientasi pada tujuan, mengorganisasi sesuatu dan pencapaian prestasi. Mahasiswa dengan conscientiousness tinggi dapat menampilkan perilaku caring yang tinggi. Orang dengan kesadaran tinggi (conscientiousness) cenderung sensitif, berhati nurani, pekerja keras, terorganisir,tepat waktu, ambisius, dan gigih. Karakteristik ini dibutuhkan dalam pekerjaan sebagai perawat yang harus melakukan setiap proses keperawatan dengan teratur dan sistemik sesuai faktor caratif caring menurut Watson. Sedangkan individu dengan skor rendah cenderung malas, tidak teratur, selalu terlambat, dan mudah menyerah (Begum \& Slavin, 2012). Kesadaran berpengaruh padaperilaku caring. Artinya mahasiswa dengan kesadaran yang tinggi cenderung lebih peka terhadap kebutuhan pasien.

Hasil penelitian juga menunjukkan bahwa aspek neuroticism mahasiswa keperawatan memiliki mean yang rendah. Neuroticism mengindikasikan mereka lebih cenderung khawatir, dan tidak berpuas diri. Neuroticism terdiri dari beberapa segi yang membentuk kecemasan, kemarahan, depresi, kesadaran diri, kurangnya pengendalian diri, dankerapuhan (Terry, Peck, \& Smith, 2019). Neuroticism tidak berpengaruh pada perilaku caring. Artinya mahasiswadalam penelitian ini, aspek neuroticism yang tinggi juga dapat menampilkan perilaku caring yang tinggi. Seseorang yang memiliki neuroticism tinggi ternyata tidak cocok bila ditempatkan pada tempat yang memiliki stressor tinggi. Hasil penelitian Hee \& Johari (2014) menyatakan bahwa seseorang dengan tipe kepribadian ini, tidak akan dapat bekerja dengan berorientasi kepada klien.

Aspek keterbukaan terhadap pengalaman (openness) tidak berpengaruh pada perilaku caring. Aspek keterbukaan terhadap pengalaman (openness) adalah sikap seseorang yang menunjukkan bagaimana menerima perubahan yang terjadi di lingkungan. Individu dengan keterbukaan yang tinggi cenderung memiliki imajinatif, kreatif, orisinal, suka keberagaman, penuh keingintahuan dan bebas. Sedangkan individu dengan keterbukaan rendah terhadap pengalaman cenderung tidak kreatif, suka rutinitas, tidak mau tahu, dan konservatif (Terry et al., 2019). Orang dengan karakteristik kepribadian openness akan cenderung menyukai seni, menyukai variasi, tidak terlalu terpaku terhadap hal-hal yang tradisional dan suka berinovasi (Feist, 2009). Karakteristik mereka yang tidak suka diatur dan bebas, membuat orang dengan tipe kepribadian ini sulit menjadi seorang perawat yang pada dasarnya bekerja sesuai prosedur.

Aspek extraversion tidak berpengaruh pada perilaku caring. Seseorang yang memiliki kecenderungan ekstraversi tinggi akan perhatian, mudah untuk bercerita dengan orang lain, berbicara aktif, menyukai humor, aktif dan antusias. Extraversion tidak ada pengaruhnya pada perilaku caring. Artinya mahasiswa dengan extraversion yang tinggi tidak berarti memiliki perilaku caring yang tinggi. Hal ini karena perilaku caring tidak hanya dipengaruhi tipe kepribadian, tetapi bisa dari luar individu mahasiswa itu sendiri seperti beban tugas, motivasi ataupun yang lainnya. Hasil penelitian ini berbeda dengan penelitian yang dilakukan oleh Sinurat \& Novieastari (2016) yang mengatakan ada hubungan tipe kepribadian extraversion dengan perilaku caring. Karakteristik tipe kepribadian extraversion yang ramah dan mudah bersosialisasi membuat seseorang menjadi mudah berinteraksi dengan orang lain. Jika dikaitkan dengan keperawatan maka didapatkan bahwa kemampuan berinteraksi akan mendukung perawat dalam memberikan pelayanan caring.

Aspek agreeableness berpengaruh terhadap perilaku caring mahasiswa keperawatan. Pribadi dengan tingkat keramahan yang tinggi cenderung lembut, orang yang percaya, murah hati, suka damai, pemaaf, dan baik hati. Sedangkan pribadi dengan skor rendah cenderung kejam, pelit, selalu mengkritik, dan mudah terluka (Penney, David, \& Witt, 2011). Seibert \& Kraimer (2001) dalam Hee \& Johari (2014) mendefinisikan agreeableness sebagai suatu kontinum mulai dari membantu orang lain, percaya, baik hati, berhati lembut, hangat dan kooperatif. Individu yang agreeablenes memiliki kecenderungan untuk melakukan lebih dari yang diminta. Melakukan sesuatu untuk orang lain seperti dia akan melakukannya untuk diri sendiri merupakan salah satu aspek dari caring menurut Swanson (Sumarni, 2020). Hal tersebut menunjukkan bahwa karakteristik yang dimiliki tipe kepribadian ini akan mendukung seorang perawat untuk berperilaku caring. Hasil ini didukung dari hasil penelitian sebelumnya oleh Hee \& Johari (2014) yang menyatakan bahwa seseorang dengan skor tinggi pada kepribadian agreeablenes akan mampu bekerja dengan baik dan berorientasi pada pasien. 


\section{KESIMPULAN DAN SARAN}

Mahasiswa keperawatan dengan tipe kepribadian agreeablenes dan conscientiousness mampu menunjukkan perilaku caring yang tinggi. Saran bagi institusi pendidikan agar pendidik keperawatan lebih fokus pada pemberian role model bagaimana hal yang benar dalam mempraktikkan perilaku caring sebagai sarana untuk meningkatkan perilaku caring mahasiswa keperawatan dan adanya screening tipe kepribadian di awal mahasiswa masuk. Proses pembelajaran yang dapat membentuk karakter dan perilaku caring di instansi pendidikan perlu ditingkatkan lagi. Dosen dapat membantu mahasiswa untuk memahami kepribadian masing-masing melalui proses belajar mengajar. Saran bagi peneliti selanjutnya, diharapkan cakupan sampel lebih luas dan memperhatikan suku responden atau faktor lain yang mempengaruhi tipe kepribadian.

\section{REFERENSI}

Afidah. (2011). Hubungan antara Tipe Kepribadian dengan Kinerja Perawat di Rumah Sakit PKU Muhammadiyah Surakarta. Naskah Publikasi.

Agustin, I. (2002). Perilaku caring perawat dan hubungannya dengan kepuasan klien di Instalasir Rawat Inap Bedah Dewasa di Rumah Sakit Dr. Mohammad Hoesin Palembang.

Begum S., \& Slavin, H. (2012). Perceptions of "caring" in nursing education by Pakistani nursing students: An exploratory study. Nurse Education Today.

Eley, D., Eley, R., Bertello, M., \& Rogers-Clark, C. (2012). Why did I become a nurse? Personality traits and reasons for entering nursing. Journal of Advanced Nursing, 68(7), 15461555.https://doi.org/10.1111/ j. j.1365648.2012.05955.x

Feist. (2009). Theory of Personality 7ed. New York: Mc Graw Hill.

Fusnika. (2014). Pembinaan Civic Disposition berbasis Nilai-Nilai Kemanusiaan Pada Pembelajaran Pendidikan Kewarganegaraan di Sekolah Tinggi Ilmu Kesehatan Kota Sukabumi Universitas Pendidikan Indonesia.

Gunarsa. (2010). Psikologi Perawatan. Jakarta: Gunung Mulia.
Hee, O. C., \& Johari, H. (2014). A Conceptual Analysis of Personality Traits and Customer-Oriented Behaviour in the Health Tourism Hospitals. International Journal of Caring Sciences, 7(2), 368-374.

Hee, O., \& Johari, H. (2014). A Conceptual Analysis of Personality Traits and Customer-Oriented Behaviour in the Health Tourism Hospitals. International Journal of Caring Sciences, 7(2).

Labrague, L. J. (2012). Caring competencies of baccalaureate nursing students of samar state university. Journal of Nursing Education and Practice, 2(4), 105-113. https://doi.org/ 10.5430/jnep.v2n4p105.

Labrague, L. J., Mcenroe-petitte, D. M., Papathanasiou, I. V, Edet, O. B., Arulappan, J., \& Tsaras, K. (2015). Caring Behaviors: A Multicountry Study Search terms : Author contact: The Offiicial of NANDA International Inc, 28(4), 225-232.

Nasution, S. S., \& Ariga, R. A. (2018). Hubungan Kepribadian Dengan Tingkat Prestasi Mahasiswa di Fakultas Keperawatan Universitas Sumatera Utara. Talenta Conference Series: Tropical Medicine (TM), 1(1), 6-12. https://doi.org/10.32734/tm.v1i1.31.

Nurhayati, N. (2018). Model Peningkatan Perilaku Caring pada Mahasiswa Jurusan Keperawatan Politeknik Kesehatan Kemenkes Pangkalpinang. Jurnal Kesehatan, $9(2), \quad 225$. https://doi.org/10.26630/jk.v9i2.775.

Nursalam, N., Wijaya, A., Bakar, A., \& Efendi, F. (2015). Indonesian Nursing Students in Caring Behavior. GSTF Journal of Nursing and Health Care, 2(2). https://doi.org/10.5176/2010-4804_2.2.75.

Pardede. (2020). Tipe Kepribadian Berhubungan Dengan Perilaku Caring Perawat. Jurnal Keperawatan Silampari, 28(2), 1-43. Retrieved from http://journals.sagepub.com/ doi/10.1177/1120700020921110.

Parvan K, Hosseini F, Z. V. (2012). Professional Values from Nursing Students' Perspective in Tabriz University of Medical Sciences: a Pilot Study. IJN, 25(76), 28-41. Retrieved from http://ijn.iums.ac.ir/article-1-1282en.html. 
Penney, L. M., David, E., \& Witt, L. A. (2011). A review of personality and performance: Identifying boundaries, contingencies, and future research directions. Human Resource Management Review, 21(4), 297-310. https://doi.org/10.1016/j.hrmr.2010.10.005.

Richardson, C., Percy, M., \& Hughes, J. (2015). Nursing therapeutics: TEACHING student nurses care, compassion and empathy. Nurse Education Today, 35(5), e1-e5. https://doi.org/10.1016/j.nedt.2015.01.016.

Roe. (2009). The relationship between pre-licensure baccalaureate nursing students' stress and their perceptions of clinical nurse educator caring. ProQuest Dissertations Publishing. Louisiana State University Health Sciences Center School of Nursing.

Sholichah. (2015). Hubungan Tipe Kepribadian (Big Five Personality) dengan Perilaku Caring pada Mahasiswa Pendidikan Ners PSIK FK Universitas Gajah Mada. Naskah Publikasi FK $U G M$.

Sinurat, T., \& Novieastari, E. (n.d.). Trait Kepribadian Memengaruhi Perilaku Caring Mahasiswa Profesi Fakultas Ilmu Keperawatan Universitas Indonesia. Naskah Publikasi FK UI, 1-11.

Strout, K. (2012). Wellness promotion and the institute of medicine's future of nursing report: Are nurses ready? Holistic Nursing Practice, 26(3), 129136.https://doi.org/10.1097/HNP.0b013e31824ef 581.
Sulisno, M., \& Ulfa, I. H. (2015). Interaksi Caring Mahasiswa Keperawatan Tingkat I, II, dan III [Caring Interaction between Nursing Students in Year I, II, and III]. Jurnal Managemen Keperawatan, 3(1), $36-41$.

Sumarni. (2020). Monograf: Peran Pembimbing Klinik dalam Pembentukan Perilaku Caring dan Self Efficacy Mahasiswa. Purwokerto: UHB Press.

Sumarni, T. (2016). Perilaku Caring pada Mahasiswa Keperawatan D3 STIKES Harapan Bangsa Purwokerto.

Terry, D. R., Peck, B., \& Smith, A. (2019). Is nursing student personality important for considering a rural career?33(5), 617634. https://doi.org/10.1108/JHOM-032019-0074

Watson. (2012). Assessing And Measuring Caring In Nursing And HealthScience (2nd ed). New York: Springer.

Zamanzadeh, V., Valizadeh, L., Azimzadeh, R., Aminaie, N., \& Yousefzadeh, S. (2014). First and Fourth-Year Student's Perceptions about Importance of Nursing Care Behaviors: Socialization toward Caring. Journal of Caring Sciences, 3(2), 93-101. https://doi.org/10.5681/jcs.2014.010 